\title{
MulHeres, Cinema e História: Retratos de GUeRRA e HeMingWAy \& MARTHA
}

WOMEN, CINEMA AND EMPOWERMENT: AN ANALYSIS OF THE FILMS MARGARETH BOURKE-WHITE (1989), AND HEMINGWAY \& GELLHORN (2013)

\author{
Júlio Cesar Lobo* \\ jclobo2000@yahoo.com.br
}

RESUMO: O objetivo principal desse ensaio de análise fílmica é destacar uma certa reversão na subrepresentação feminina na mídia contemporânea, relativa às coberturas de guerras por parte de mulheres protagonistas, e em funções ativas, tomando como corpus os filmes de ficção norteamericanos Retratos de guerra (1989) e Hemingway \& Martha (2013). O nosso enfoque prioriza a análise de mensagens, destacando a discussão das relações de gênero e patriarcado (as protagonistas são casadas), em que se incluem tópicos relativos a machismo, testes de virilidade e preconceitos contra a mulher, além de realçar, através das mídias enfocadas, o papel do jornalismo como fonte de testemunho, de denúncia e de memória. A articulação interdisciplinar que se propõe aqui inspira-se em discussões teóricas e metodológicas nos campos da Teoria do Jornalismo, estética cinematográfica (Jacques Aumont), feminismo (Simone de Beauvoir), História (Peter Burke) e História e cinema (Robert Rosenstone). Por fim, em nosso entendimento, essas narrativas celebram dramaticamente um empoderamento feminino.

PALAVRAS CHAVE: Cinema, História, gênero, mulheres, jornalismo, guerra, empoderamento feminino.

ABSTRACT: The main objective of this essay of film analysis is to highlight a certain reversal of the feminine underrepresentation in a contemporary media, relative to the coverage of wars by women protagonists, and in active roles, taking as a corpus the American fiction films Portraits of War (1989) and Hemingway \& Martha (2013). Our approach focuses on the analysis of messages, highlighting the discussion of gender relations and patriarchy (all the the protagonistas are married), which includes topics related to machismo, virility testes and prejudices against women, besides higlighting, through focused media, the role of journalism as a source of testimony, denunciation and memory. An interdisciplinary articulation that is proposed here inspires theoretical and methodological issues in the fields of Theory of Jornalism), cinematographic aesthetics (Jacques Aumont), feminism (Simone de Beauvoir), História (Peter Burke), and História e cinema (Robert Rosenstone). Finally, in our understanding, these narratives dramatically celebrate a feminine empowerment.

KEYWORDS: Cinema, History, gender, women, journalism, war, feminine empowerment.

\footnotetext{
* Doutor em Estética da Comunicaçao pela Universidade de São Paulo. Professor-titular aposentado do Departamento de Ciências Humanas da Universidade do Estado da Bahia. Professor-associado IV da Faculdade de Comunicação da Universidade Federal da Bahia.
} 
A passividade, que caracterizará essencialmente a mulher 'feminina' é um traço que se desenvolve nela desde os primeiros anos. Mas é um erro pretender que se trata de um dado biológico. Na verdade, é um destino que lhe é imposto por seus educadores e pela sociedade [...]. Ser feminina é mostrar-se impotente, fútil, passiva dócil. A jovem deverá não somente enfeitar-se, arranjar-se, mas, ainda reprimir sua espontaneidade e substituir, a esta, a graça e o encanto estudados, que Ihes ensinam as mais velhas. Toda afirmação de si própria diminui sua feminilidade e suas probabilidades de sedução [...]. Nos romances de aventura, são os meninos que fazem a volta ao mundo, que viajam como marinheiros nos navios, que se alimentam na floresta com a fruta-pão. Todos os acontecimentos importantes ocorrem através dos homens. A realidade confirma esses romances e essas lendas.

BEAUVOIR, S. O segundo sexo 2. A experiência vivida, 1980.

O movimento feminista e as teorias a ele relacionadas encorajaram os historiadores e as historiadoras a fazerem novas perguntas a respeito do passado. Sobre a supremacia masculina, por exemplo, em diferentes tempos e lugares: era realidade ou mito? Em que medida e como essa supremacia poderia ser rechaçada? Em que regiões e períodos e em que domínios - no seio da família, por exemplo, as mulheres exerceram influência não-oficial? Outra série de perguntas diz respeito ao trabalho das mulheres. Quais espécies de trabalho eram realizadas pelas mulheres em lugares e épocas específicos? $\mathrm{E}$ quais as regras e convenções para ser mulher ou homem de uma faixa etária ou grupo social específicos em uma determinada região e período específico

BURKE, P. História e teoria social, 2002.

\section{Introdução}

Tão antiga quanto a história do desenvolvimento do cinema como forma narrativa de massa é a presença da imprensa como tema de filmes de ficção. O registro mais longínquo que se tem dessa aproximação data de 1904 com um curta-metragem desaparecido: The power of the press. Em 1928, Frank Capra rodaria um título homônimo no apagar das luzes do cinema silencioso. Esse subgênero, no entanto, somente começaria a obter algum prestígio sob a batuta de Howard Hawks em Jejum de amor (His girl Friday, 1940), a segunda adaptação de um sucesso da Broadway: The front page. Um dado importante que poderia ser associado a esse marco é ter uma repórter policial (Rosalind Russel) como coprotagonista. Foram necessárias que várias décadas se passassem até que uma jornalista pudesse ocupar novamente um lugar de destaque na ficção de matriz hollywoodiana. Isso aconteceu em 1989 com o telefilme Retratos de guerra. Vale notar que há mais um ponto importante de contato entre esses dois títulos norte-americanos. A interferência do casamento no cotidiano dessa profissional. Pelo fato de Jejum de amor não tratar de repórteres de combate - os chamados correspondentes de guerra - deixamos de inclui-lo em nosso corpus nesse artigo. 
No intervalo de quase meio-século que separa Jejum de amor de Retratos de guerra, muita coisa aconteceu, principalmente fora das telas, com relação ao que os filmes, que serão analisados nesse texto, dramatizam: direito de voto às mulheres, direito ao aborto, divórcio em países católicos, guarda compartilhada dos filhos, mulheres em postos-chave na administração de empresas jornalísticas, etc. O que buscaremos destacar a seguir é como as narrativas ficcionais, cinebiografias, como Retratos de guerra e Hemingway dramatizam questões relativas à cultura profissional de jornalistas (imprensa e poder e valor-notícia, ou seja aquilo que deve ser publicado), vocação, compromisso social, função social da fotografia e questões de gênero, principalmente a situação da mulher independente - como se dizia antigamente - frente ao patriarcado. Veremos, mais abaixo, como uma câmera fotográfica pode se tornar uma arma - em inglês o verbo para atirar é o mesmo que é usado para "tirar" fotos: to shoot- , combatendo um bom combate, entre outras coisas. A despeito da distância temporal por nós frisada, é estimulante notar-se como Jejum de amor tematiza aspectos que são relevantes na abordagem dos filmes Retratos de guerra e Martha \& Hemingway, a saber:

Apesar de ser o elo comum entre os jornalistas de The front page [a dupla masculina da peça original, adaptada em Jejum de amor], [vemos] que a definição esquemática da vocação derivava, na peça, de sua inscrição, por convenção dramática, numa série de oposições consagradas da cultura americana. Trabalho/amor: Hildy estava dividida entre o amor da mulher e a profissão; masculino/feminino: o mundo do jornalismo é eminentemente masculino e excluída o universo feminino, representado por personagens menores; trabalho/família: os jornalistas negligenciam as famílias em virtude da profissão demasiado absorvente" (SENRA, 1997, p. 79).

O que mais nos chamou a atenção na amostra das narrativas escolhidas, do ponto de vista temático, como motivação inicial para o planejamento desse nosso texto foi a atenção dada a tópicos de um certo patriarcalismo, notadamente à gravidade com que os esposos de nossas protagonistas encaram as ocupações dela. Por isso, elas, em intensidades variadas, irão enfrentar problemas de afirmação (consolidação de identidade pessoal) ao passo que atravessam, de certa forma, um romance de formação, profissional. Elas encaram, nos momentos mais tensos dessas narrativas, uma luta em vários fronts, especialmente o que poderíamos chamar - parafraseando o título de um livro de contos de Dalton Trevisan - de guerra conjugal.

Se podemos creditar a Jejum de amor o pontapé inicial mais vigoroso de uma representação de questões de gênero em filmes de jornalistas, talvez possamos apontar outro 
pioneirismo, em termos temáticos, a outra produção norte-americana, o hitchcockiano Janela indiscreta (Rear window, 1954). Nesse thriller, há uma inversão de gênero com relação a protagonista, mas isso não impede a sua lembrança ao que iremos discutir mais adiante. Jeff (James Stewart) é um repórter especializado em coberturas de risco, que se recusa a se casar com uma bela, elegante e bem-nascida jornalista de modas (Grace Kelly) devido a peculiaridades de sua ocupação, ao seu modo de vida tão atrelado à sua especialidade no mundo do jornalismo norte-americano. Ou seja, de certa forma, ele busca se antecipar aos problemas que os maridos das protagonistas de nosso corpus de análise vão enfrentar. Reproduziremos trechos do seu diálogo anticasamento:

- Você já comeu cabeça de peixe com arroz? É claro que não. Talvez preciso fazer isso se for me acompanhar.

- Já tentou se aquecer a 4.500 metros, com 20 graus abaixo de zero?

- Sempre depois do almoço [uma referência ao fato de quase nunca poder almoçar ou jantar com Jeff].

- Você já levou um tiro? Já foi atropelada? Já apanhou de alguém que não gostou da publicidade gerada por ter sido fotografada? Esse sapato alto, que você usa, seria perfeito para a selva, como a lingerie que você usa. Você faria sucesso na Finlândia antes de morrer congelada.

- Usar a roupa certa é algo que sei fazer.

- Você não encontrará capas de chuva no Brasil mesmo que não esteja chovendo [sic]. Lisa, nesse meu trabalho, só se pode carregar uma mala. A sua casa é o transporte disponível. Não se dorme muito, banha-se menos ainda. E, algumas vezes, a comida é preparada com coisas que nunca olharíamos se elas estivessem vivas.

Fizemos essa longa citação acima porque ela nos parece ter sido a inspiradora de muitas cenas e sequências que celebram o repórter (masculino) de guerra. Na verdade, o tema do diálogo azedo é, de uma certa maneira, uma adaptação proveniente da vida real mesmo, envolvendo talvez o mais famoso repórter de combate de todos os tempos - e presente em Martha \& Gellhorn -, o húngaro-americano Robert Capa (1913-1954), e a atriz sueca Ingrid Bergman (1915-1982). Ao Ihe propor casamento, quando ainda estava casada com um médico de seu país natal, ela ouviu dele o argumento de que, casados, ele não teria mais a liberdade para cobrir situações de risco, em que havia se destacado na Europa, e que Ingrid não poderia acompanha-lo Ingrid contou a desculpa a Hitchcock, que a ampliou, mantendo o mesmo espírito, o cultivo à eterna solteirice (WHELAN, 2010). 
O que o diálogo acima de Janela indiscreta já sinalizava nos distantes anos 1950 era um aspecto para o qual nos chama a atenção uma ensaísta brasileira para aquilo que era tido durante muito tempo como um senso comum de que o "mundo do jornalista" era essencialmente masculino. Mas por quê? Argumenta Stela Senra (1997, p. 49): “[...] a crueza dos fatos, a disparidade dos meios sociais por ele [o jornalista] frequentados, sua jornada, principalmente, noturna de trabalho e o risco de certas situações a serem enfrentadas não se adequavam à presença feminina". Essa é a síntese de um do qual veremos exemplos pontuais, notadamente no filme sobre Margareth Bourke-White.

\section{Uma pioneira chamada Margareth}

O telefilme Retratos de guerra (Margareth Bourke-White, EUA, 1989, dir. Lawrence Schiller) se inicia com uma espécie de prólogo, que caracteriza rapidamente o contexto sociocultural com que a biografada terá que lidar nos Estados Unidos e na cobertura da Segunda guerra mundial. Alojamento do 3ำ Exército americano, unidade comandada pelo general Patton (Mitchell Ryan), Margareth Bourke White (1904-1971), interpretada por Farraw Fawcett Majors, se dirige na direção desse comandante, aguardando instruções. Ele comenta com alguns auxiliares: "Olha, como ela vem caminhando à vontade. Típico de mulher". Há uma explosão. Patton cai, protegendo-a, ao que ela responde que é uma pessoa de sorte ao que ele contrapõe que ela teve sorte de ter estado ali, sob um abrigo, mas que as bombas também caem em cima da sorte ou de pessoas sortudas. Ele encerra o encontro casual, perguntando-Ihe se ela também vai se arriscar por uma foto.

Do prólogo, com Patton, em corte seco, vai-se para o que - perceberemos logo - para um flashback, acionado pela instância narrativa. Estamos agora em Cleveland (EUA), chega o ex-marido da protagonista, informação que ela esconde de seus parceiros na fotografia que faz de fábricas, siderúrgicas, prédios comerciais, o que é denominado por eles de "fotografia arquitetural". O ex-marido manifesta no reencontro não esperado por ela a vergonha que ele sentia pela ocupação da mulher. Estamos nos anos 1920. Surge logo o discurso dela para responder às cobranças, vindas de várias alçadas, de não ser à época uma mulher casada [ela já havia sido] ao que responde: "Não sou o tipo de pessoa que pode ou deve se casar. Não posso remediar isto. Quero experimentar de tudo". A primeira frase dessa fala remete-nos, por exemplo, inevitavelmente ao protagonista de Janela indiscreta, mencionado mais acima. Por outro lado, a resposta de Margareth também pode servir como uma contrafação ao que 
aponta Simone Beauvoir (1980) na primeira epígrafe desse texto quando ela afirma que, nos romances de aventura, "todos os acontecimentos importantes ocorrem através dos homens".

Margaret intenta fotografar uma grande metalúrgica (Otis Steel), mas o seu diretorgeral não concorda com isso, argumentando que a entrada naquela planta industrial era vetada às mulheres por questões de segurança e porque muitas das que a antecederam naquele intento haviam desmaiado devido às altas temperaturas. Essa primeira negativa fortemente sexualizada claro que é recusada por Margaret ${ }^{1}$. O resultado é que as fotos aí obtidas a credenciam junto ao publisher Henry Luce (1898-1967), interpretado por Jay Patterson, a coloca-la na primeira equipe de repórteres-fotográficas de um projeto dele muito ansiado: a revista LIFE. Uma publicação que ele previa ser capaz de fazer da câmera fotográfica uma intérprete, tratando com o mesmo interesse as imagens de um trator e aquelas de um presidente da República. Do ponto de vista temático, a ideia de Luce era contar a história industrial dos Estados Unidos, tomando a câmera como uma parceira da letra impressa.

A despeito do interesse que Luce tem em incorporar Margaret em seu citado projeto, já se considerando o patrão dela, num coquetel, ele não deixa de salientar que não se observava - àquela época, anos 1920 - mulheres trabalhando, viajando sozinhas e que estava surpreso com o fato de ela não ser casada e que só vivia para o trabalho. Diante do sacerdócio que a fotografia começava a se apresentar para a vida de Margaret, Luce diz-Ihe não acreditar que uma moça tão bonita não vá a bailes, ao que ela responde: "Nunca consegui dançar e tocar algum instrumento ao mesmo tempo". As observações que Luce faz acima a Margareth parecem-nos um discurso sutil em torno de um "ideal feminino" para o que aponta Pedro Paulo de Oliveira (2004, p. 71):

Como contraponto ao ideal moderno de masculinidade, emergiu, paralelamente o ideal feminino. Enquanto o masculino simbolizaria a ordem e o progresso, o feminino deveria expressar a castidade, a pureza, o comedimento público e outras características que não confrontavam a submissão da mulher às figuras masculinas, pais e maridos, sobretudo. Ao homem cabia a produção do novo, as conquistas, o avanço: à mulher, a

\footnotetext{
${ }^{1}$ Uma excelente seleção da produção dela nesse período de fotografia industrial ou de arquitetura está no livro Margaret Bourque-White, photographer, editado por Maryann Kornely e Debra Cohen (Boston: Bulfinch, 1998) com imagens de montadoras de automóveis (Ford, Detroit,1929), montadores de tratores (Stalingrado, 1930), siderúrgicas (Aluminum Company of America, 1930; Bethlehem Steel, Baltimore, 1935), tecelagem, chaminés (Otis Steel, Cleveland, 1928), laboratórios químicos, alojamentos de operários (1930), monumentos (Estátua da Liberdade, 1930), estaleiros etc. Como exemplos de correspondência de guerra, têm-se instantâneos do bombardeamento de Moscou pelos nazistas (1941), ações da Artilharia norte-americana no sul da Itália (1944), fugas de alemães de Berlim, campos de concentração em vários pontos da Alemanha, entre outras preciosidades.
} 
reprodução do conquistado, a manutenção do passado, a submissão e a dedicação aos heróis. Os ideais assim configurados buscavam neutralizar a ideia de que o domínio público era assunto masculino, enquanto o doméstico ficaria a cargo das mulheres.

É claro que levou algum tempo para que Margaret começasse a fazer a travessia da fotografia "arquitetural" - como ela o chamava - para o fotojornalismo propriamente dito onde valem mais os valores-notícia (aquilo que justifica a veiculação de uma notícia) do que elementos de estilo de composição fotográfica. Uma prova disso é que, estando no interior de um grande banco norte-americano no dia da quebra de Bolsa de Valores, ela não havia feito nenhuma foto das pessoas angustiadas em retirar suas economias, nem das pessoas alarmadas por terem perdido tudo no famoso episódio que marcou o ano de 1929 nos Estados Unidos.

\section{Imagens da pobreza}

O fato é que Margaret sente que o início da Depressão, que se seguiu ao histórico crack, acaba motivando-a a fazer algo mais: ela acaba se oferecendo para trabalhar com o romancista Erskine Caldwell (1903-1987), interpretado por Frederic Forrest, que havia recebido uma encomenda de produzir uma longa reportagem sobre a "realidade da pobreza" nas cidades do Sul profundo [Deep South]. É curiosa a expressão utilizada por Erskine para definir a sua empreitada porque ela parece uma contraposição irônica ao que Margaret vinha fazendo antes de conhecê-lo: fotografando as grandes indústrias norte-americanas, ou seja, um pouco da história da riqueza nos Estados Unidos. Inicialmente, esse escritor, já famoso, recusara a parceria da prestigiada fotógrafa da Life, criticando o trabalho dela, dizendo que as suas fotos tratavam as pessoas como se fossem coisas, como se elas estivessem numa linha de montagem. Pudera, ela se iniciara na profissão fotografando máquinas...

A longa e atribulada empreitada da dupla - e posterior casal - pelo chamado Deep South acaba puxando outra: uma encomenda da Life para ela ir à União Soviética. Ao traçar a rota marítima e aérea que os dois deveriam obedecer para chega a Moscou "por trás", Luce já dá uma pequena ideia, principalmente à repórter fotográfica, dos percalços de uma cobertura em tempos de expansão imperialista do nazismo. Pouquíssimo é mostrado dessa viagem. Na verdade, tem-se apenas uma curta e relaxada sequência com o presidente da República Soviética da Ucrânia. Sequência, na verdade, que somente serve para mostrar como funcionava a máquina de delação no governo de Stálin. No retorno, em entrevista no 
aeroporto, já famosa, voltam as questões de gênero, que marcam esse filme: ela informa aos presentes que, na União Soviética, as mulheres "fazem de tudo", presentes até em minas cuja proibição talvez seja um tabu quase universal. Mais ainda - o que Margaret não diz: desde a segunda metade dos anos 1920, todas as jovens soviéticas eram obrigadas a ter uma formação militar, ficando cadastradas como "simples soldado" (entre 18 e 40 anos de idade) e oficiais (entre 18 e 45 anos de idade). Ainda havia outras que formavam a "reserva de mão de obra" (QUÉTEL, 2009).

Além de enfrentar as resistências de uns e outros a uma mulher, que é fotojornalista, Margaret começa a enfrentar o ciúme de Erskine ("A revista Life não é vida; eu sou a vida", por sinal, um trocadilho que se perde na tradução para o português), incomodado com a jornada de trabalho dela que invade os espaços do jantar e da ida ao teatro, especialmente em suas estreias. Em síntese, Erskine se depara com a "natureza bifacetada do trabalho jornalístico" na qual se destaca "como pano de fundo permanente, uma tensão constante entre o caos e a ordem, a incerteza e a rotina, a criatividade e o constrangimento, a liberdade e o controle" (TRAQUINA, 2005, p. 194). O fato é que, já divorciada e muito ciosa da importância social do seu trabalho, Margaret acaba cedendo ao pedido de casamento de Erskine, mas estabelece as condições para o casamento, em que há uma "cláusula pétrea", digamos: "Serei paciente e não tirarei minha esposa do seu trabalho". É possível que a maioria dos telespectadores masculinos ria dessa fala, principalmente porque ela a enuncia com um certo humor, mas tratava-se de um assunto sério e que será retomada mais adiante. Casamse.

Casados, uma outra das conversas mais constantes entre Erskine e Margaret é sobre o desejo dele de ter um filho, mais propriamente uma filha, que já teria até um nome: Patricia. Como uma forma de acalmá-lo, Margaret compra uma casa ampla e confortável em uma área rural, achando que, lá, o seu marido teria as mínimas condições para voltar a escrever sua ficção. Aparentemente, ele enfrenta um período de crise, um tema, de certa forma, recorrente em filmes norte-americanos da matriz Nasce uma estrela (A star is born, 1937; 1954; 1973; 1976; 2003; e 2010) em que, ao sucesso da esposa artista, corresponde o declínio criativo do marido, músico ou escritor. Uma frase marcante dele a esse respeito é quando, ao final de um dia em que só fez rasgar inícios, diz-Ihe melancolicamente que um escritor de ficção, como ele, tem apenas "uns 10 bons anos". 
Com alguma resistência da parte de Erskine, o casal vai novamente à União Soviética, por incumbência de Luce, seguindo pistas de uma eventual invasão de Moscou pelas tropas de Hitler. O fato é que Margaret consegue fazer flagrantes dos primeiros combates por mais de 24 horas o que, mais uma vez, desperta a incompreensão do famoso marido, indagandoIhe - mas como não precisando de resposta-, como era que ela conseguia trabalhar tantas horas seguidas. A resposta da esposa mostra-a contente com o resultado e não com o processo: "Consegui, não é? Eu sabia do ataque e consegui a foto". Ao que ele contraargumenta que ela quase havia morrido para obtê-la. Margareth procura encerrar a conversa, cujo tema já havia adornando o casamento, desse modo: "Mas essa é a questão. A foto poderia ter me custado tudo, mas ela significa tudo". A resposta do marido desconsidera tudo o que vinha dizendo, no sentido de afirmação profissional e identidade pessoal, enfim: "Eu quero um lar; quero um filho".

\section{Segundo divórcio e outras guerras}

Na terceira volta de viagem do famoso casal a serviço, a presença da imprensa no aeroporto é uma boa oportunidade para que a prática de independência e de afirmação de gênero que Margaret vem desenvolvendo desde o início retorne, agora, em discurso. Alguém Ihe pergunta como era ser mulher na guerra. Ao que ela responde prontamente como uma mulher que, desde os 18 anos, já estaria trabalhando em ocupações tidas como "masculinas": "Ser mulher na guerra... bem, quem você acha que morre nas cidades bombardeadas? Por que eu devo ser mais forte do que o povo das cidades sitiadas?" Essa entrevista coletiva é ciumentamente encerrada por Erskine: "Porque você é minha esposa e quero mantê-la viva". Ao que ela rebate: "Você vai ter que esperar pelo meu trabalho". A próxima imagem de força de Margaret temos com ela dormindo no alojamento do 3ํ Exército americano na Europa, na Segunda guerra mundial, agregada às tropas do general Patton, o mesmo que vimos no prólogo, protegendo-a de um ataque bélico. Ela recebe um telegrama de Erskine, curto e grosso, notificando-a de sua vontade de dela se separar. Não há tempo para choros e velas, pois, logo em seguida, teremos Margaret preparando o seu espírito para colher imagens de pilhas e mais pilhas de cabeças, retirada dos fornos de um desativado campo de concentração dos nazistas.

De uma certa forma, a repórter de combate Margaret Bourke-White nessa cinebiografia acaba sendo um símbolo da presença feminina em campos de batalha. Tivemos 
ela como protagonista da mesma forma que talvez pudéssemos ter tido a dramatização de trajetórias de muitas outras que, como repórter de texto ou de imagens, estiveram em vários campos de batalha como Jimmie Broughton (de Ohio, EUA), a britânica Iris Carpenter (Daily Express, Daily Herald e Boston Globe) e Martha Gellhorn, entre outras. Se, no começo do filme sobre Margaret, o ex-marido dela sentia-se envergonhado por surpreendê-la em terraços de fábricas trabalhando, imagine-se então vê-la partir para a cobertura da Segunda Guerra Mundial.

O filme Retratos de guerra vai se encerrando com reproduções de trabalhos da verdadeira Margaret Bourke-White enquanto a locação em voz over enumera sumariamente por onde ela esteve depois: Índia, durante o final de sua luta pela libertação do domínio colonial, a guerra entre as duas Coreias, e o início das primeiras manifestações antiapartheid na África do Sul. Em 1954, segundo o locutor da narração, a protagonista começaria mais uma guerra, dessa vez contra o mal de Parkinson, que a derrotaria mortalmente em agosto de 1971. A última palavra desse biopic (biographical picture, como o chamam os norteamericanos) é com ela mesma na voz de Farraw Fawcett: "Minha vida e minha carreira não foram um acidente; tudo foi pensado a fundo".

\section{Um romance de formação e outro de afirmação}

O filme Hemingway \& Martha (Hemingway \& Gellhorn, EUA, 2012, dir. Philip Kaufman) começa com a protagonista, a despeito de ser o segundo nome no título, Martha Gellhorn (1908-1998), interpretada por Nicole Kidman, encarando o espectador, dando início a um longo depoimento, que saberemos ao final, tratar-se de uma entrevistara para uma tv. Esse enquadramento e logo de início nos informa ser dela o ponto de vista a ser desenvolvido. E tudo começa quando ela conhece Ernest Hemingway (1899-1961), interpretado por Clive Owen, num bar em Cuba. A transformação dela de contista da revista norte-americana Collier's em uma das mais respeitadas correspondentes de guerra de língua inglesa do século XX principia quando ela se encontra em Madri ao lado de jornalistas, escritores e militantes comunistas, participando, com máquina de escrever, câmeras de escrever ou de filmar e com fuzis, das com as Brigadas Internacionais, junto aos republicanos, os antifranquistas.

'Os dados de gênero tornam-se muito frequentes na caracterização dela como uma correspondente de guerra, principalmente por ter estado, desde a sua chegada `a Espanha, associada com Hemingway ("Hem”) e suas demonstrações privadas e públicas na direção de 
representações de uma masculinidade hegemônica. Isso para não nos referirmos mesmo a um culto à virilidade, seja nas primeiras imagens dele pescando um peixe enorme nos mares de Cuba, em seus treinos de boxeador amador com amigos ou nos testes de absorção de grandes quantidades de bebida alcoólica. Assim sendo, Gellhorn - nome com o qual é mais frequentemente chamada no filme, inclusive pelo coprotagonista -, que já havia chamado a atenção dele por sua beleza, sensualidade e inteligência quando se conheceram - passa a ganhar efetivamente o respeito do machão "Hem" após sair do hotel em que todos eles estavam alojados, atravessar a rua em frente sob bombardeiros para atender ao choro de uma criança ao lado da mãe morta. O que essa sequência sugere é que, para "Hem", Gellhorn teria sido mostrado "homem" ao fazer aquilo. Mais adiante, ele lhe aponta um talento para narrativas e cobra-Ihe a sua materialização: "Você deveria ser uma correspondente de guerra. Onde está a sua correspondência?". Até então, ela ainda não havia escrito nenhuma linha de correspondência, limitada principalmente por sua falta de experiência em reportagens. Ele finaliza, irritado: “O que você é, Gellhorn? Uma maldita turista de guerra? Comece a lutar pelo que acredita".

A primeira evidência da importância do já famoso mundialmente Hemingway para a caloura em jornalismo Gellhorn é quando, ao confessar-lhe não saber como transformar o que viu para que outros se informem ou se solidarize com os republicanos - via compaixão, por exemplo - ele Ihe diz simples e irritadamente: "O truque é escrever como as pessoas falam. A maioria das pessoas não as escuta". O curioso é que, ao longo do filme, veremos algumas vezes - e principalmente na última pergunta que lhe faz o entrevistador da citada entrevistara para a tv - que dicas preciosas como essas de Hemingway farão com que os méritos dela não tenham sido devidamente atribuídos enquanto ela estivera como amante dele e, depois, como esposa. Enquanto "Hem" dá a entender que a coragem dela, que ele considera como a maior demonstração que já vira numa mulher, poderia ser um bom atributo para ser uma correspondente de guerra, ela sente que seu texto ainda se ressente de algo mais, buscando no talento do fotógrafo húngaro-americano Robert Capa (interpretado por Santiago Cabrera), um exemplo como temos, como, nesse trecho de diálogo com o mesmo:

- Quero fazer o que você faz. Da foto para o texto. Você captura aquele tema humano. Que precisa fazer algo para exercer o controle mesmo quando seu mundo está fora de controle. Quero escrever do jeito que você tira fotos. Há tanta coisa acontecendo nesta guerra e, quando me sento para escrever, não consigo pensar em nada. Qual é o seu segredo? Conte-me. 
As fotos estão lá. Você somente as faz. Se suas fotos não são boas o bastante e por que você não chegou perto o bastante.

A despeito das cenas no filme que sinalizam na motivação que Gellhorn para escrever sobre a guerra na Espanha, através dos diálogos específicos citado acima com Hemingway e com Capa, no entanto, em $A$ face da guerra, título brasileiro de sua seleção de reportagens, ela tributa o impulso fundamental para o primeiro de seus despachos como correspondente de guerra a um colega anônimo:

Semanas após minha chegada a Madri, um amigo jornalista comentou que eu deveria escrever. Era a única maneira de servir à Causa - nome solene dado pelos espanhóis à guerra na República e adotado carinhosamente por nós. Afinal, eu não era uma escritora? Mas como é que eu poderia escrever sobre a guerra? O que é que eu sabia sobre o assunto e para quem eu iria escrever? Para começo de conversa, de que era feita uma reportagem? Não era preciso que algo gigantesco e definitivo acontecesse para se começar a escrever um artigo? Meu amigo jornalista sugeriu que eu escrevesse sobre Madri. E que interesse isso teria para alguém? Perguntei. Era apenas a vida cotidiana. Ele ressaltou que não era o cotidiano de todo mundo" (GELLHORN, 2009, p. 24).

Combatendo com uma máquina de escrever

O fato é que, com uma pequena ajuda de seus amigos e, principalmente com os toques do monstro Hemingway ao lado, na guerra e na cama, a experiência da Espanha, tomando partido - indo contra os mandamentos da sagrada objetividade jornalística, Gellhorn vai se firmando em uma ocupação tida àquela época - anos 1930 - como exclusividade de homens, e homens de coragem: a correspondência de guerra ou a reportagem de combate. O curioso que a própria Martha, em um de seus livros, narra com tranquilidade a dificuldade - ou até mesmo a impossibilidade- de se narrar um combate:

Você não consegue absorver tudo o que acontece durante uma batalha. Você nem mesmo consegue ver o que acontece e, muitas vezes, não consegue entender o que está vendo. De repente, vê figuras de infantaria como formigas em silhueta contra o céu: eles provavelmente estão indo atacar aquele conjunto de casa de fazenda. Então, eles desaparecem, e você não sabe o que foi feito deles. Tanques passam serenamente sobre a crista de um morro, depois a formação é desfeita, você perde a maioria deles de vista e, em seguida, no que era um vale tranquilo, você inesperadamente vê outros tanques disparando por detrás de árvores [...]. Uma batalha é um quebra-cabeça de homens lutando, civis aterrorizados e confusos, barulhos, cheiros, piadas, dor, medo, conversas inacabadas e altos explosivos (GELLHORN, 2009, p. 157-8).

Ao voltar da Espanha para os Estados Unidos, com o adúltero Hemingway, Martha se vê elogiada publicamente pelo seu editor na Colliers: "Eu não sabia que mulher tinha 
capacidade de ser correspondente de guerra". Parece que, até hoje, muitos editores de livros também não o sabem pelo que se vê da precária presença feminina - em geral, quase restrita a Gellhorn - em antologias do tema como Reporting World War II (1995), de S. Hynes; The art of fact (1997), de K. Kerrane e B. Yagoda; The Vietnam reader (1998), de Stewart O' Nan; ou no corpus da fundamental análise The first casualty, (2004), de P. Knightley.

Gellhorn busca então qualificar o seu trabalho com o que acredita seria a consequência de sua natureza, o seu modo de ser, o que observava frequentemente e a que teria levado anteriormente às páginas literárias da revista Colliers, como o que acontece no cotidiano, marca, por sinal, dos cronistas (ele começaria a carreira literária nessa atividade) "Comecei a escrever sobre o que estava passando às pessoas". Mais especificamente, ela recorre ao duro reportar sobre as vítimas na citada entrevista para a tv:

- As pessoas falam da glória das batalhas, da varredura de governos, da majestade dos líderes, mas vá a uma cidade destruída e segure a mão das crianças queimadas e famintas e verá que não é bem assim. Meu trabalho, nosso trabalho, é dar voz àqueles sem oportunidade, ser a testemunha dos inocentes e expor as mentiras que mascaram a maldade com a retórica gloriosa [...]. Meu trabalho, nosso trabalho, é dar voz àqueles sem oportunidade, ser a testemunha dos inocentes e expor as mentiras que mascaram a maldade com a retórica gloriosa. O que sempre me encantou sobre a vida é o que está acontecendo do lado de fora. Ação. Isso, sim, é algo a ser compartilhado.

Ao longo do filme, vai sendo narrado com humor, tensão e clareza o longo processo de transformação da cronista da Collier's, que vivia sossegadamente com a mãe e um irmão, frequentando a casa dos Roosevelt, na escritora que abraça uma causa - e estar ao lado das Brigadas Internacionais lutando contra Franco na Espanha nos anos 1930 era a "Causa" - e na correspondente de guerra que não tem receio, mas sim cara de pau, em se disfarçar em auxiliar de enfermagem para acompanhar o desembarque de tropas norte-americanas na Normandia. O disfarce dela foi uma forma de enfrentar a negativa do Exército norteamericano em creditar mulheres como correspondente de guerra - tecnicamente, repórter de combate - por um motivo prosaico: a dificuldade de montar instalação sanitárias exclusivas para elas em acampamentos... Para muitos e até certo tempo, mulher em combates só como enfermeira:

Se há um uniforme que, por tradição, a mulher veste em tempos de guerra, é realmente o de enfermeira. Religiosas ou civis, essas mulheres já haviam conquistado seus títulos de nobreza durante a Primeira Guerra, levando para todo esse sangue e horror a piedosa imagem da doçura e da compaixão. As 
enfermeiras da Primeira Guerra, contudo, não são enviadas à linha de frente, onde só encontram os padioleiros, que, além do mais, sofrem pesadas perdas. Elas estão na retaguarda, cujo traçado é quase sempre delimitado, permitindo aos 'hospitais' de campanha funcionar o mais perto possível das linhas de frente, sem estar sob o fogo do inimigo (QUÉTEL, 2009, p. 184).

Em seus momentos de quase solilóquio, enfrentando o espectador - ou seja, a câmera da equipe de tv que a entrevista em sua longa rememoração -, Gellhorn, às vezes, distribui algumas qualificações à sua carreira de mais de 60 anos de coberturas internacionais que poderiam ter sito tomadas como por um representante de uma masculinidade hegemônica (como o Hemingway representado nesse filme) como atributos, digamos, de uma certa virilidade: "Eu sempre me sinto em casa nos lugares mais difíceis. Mas amor? Eu sou uma correspondente de guerra" [...]. Uma mochila e cerca de 50 dólares: esse foi o meu equipamento para a Espanha. Qualquer outra coisa seria desnecessário”. Declaração que poderíamos ter posto na boca, por exemplo, do protagonista do já citado filme Janela indiscreta

\section{Mais uma outra guerra conjugal}

Ao tempo em que Gellhorn vai ganhando prestígio como correspondente de guerra, o seu casamento com o monumento Hemingway vai enfrentando vários problemas, alguns deles devido às frequentes demandas que a revista Collier's lhe faz, para coberturas e entrevistas ao longo do mundo enquanto ele prefere longas estadias na bela casa que mantém em Cuba para que ele tenha a tranquilidade para se desvencilhar de uma encomenda de um romance para a editora Scribners. "Hem" não entende porque a sua mulher tem que cobrir todos os conflitos bélicos no planeta, como se tem nesse diálogo, iniciado por ele: "Neste mundo, quando você encontra um lugar bom [uma imensa casa isolada em Cuba], você não mais o abandona. Você só quer uma guerra para si mesma". Ao que ela rebate: "Foi você quem me ensinou isso. Algumas guerras são necessárias, e é necessário haver testemunhas".

O fato é que, naquele momento, citado acima, Gellhorn estava investindo muito em sua carreira jornalística. A relação marital se azeda quando ela recebe um convite para cobrir a invasão soviética à Finlândia o que a faz até desistir da citada encomenda literária. Mas "Hem", com medo da viagem dela, desacompanhada, e com medo de perde-la mesmo, chega a ser melodramático em sua argumentação: “Felicidade, para pessoas inteligentes, é a coisa 
mais rara que existe". Essa viagem também teve uma importância na formação profissional dela, como rememora:

Eu pensei, profissionalmente, que era uma coincidência incomum chegar a um país estranho e com gelado numa tarde escura e ser acordada na manhã seguinte às nove da manhã pelas primeiras bombas - a declaração de guerra [...]. Na Espanha, eu havia entendido o significado da guerra; vi claramente o que a guerra espanhola defendia e o que ela atacava [...] Mas esta guerra era loucura completa [...]. Imagino que a maneira pela qual as pessoas conseguem se manter parcialmente sãs na guerra é colocando em suspenso uma grande parte de suas mentes, que raciocinam, perdendo a maior parte da sensibilidade, rindo quando têm a menor chance e ficando um pouco (mas cada vez mais) loucas (GELLHORN, 2009, p. 66)

Voltando do Ártico, Gellhorn recebe outra pauta: ir à China, entrevistar Chiang Kai Shek e acompanhar a resistência à invasão japonesa. Ela tenta convencer "Hem" a ir com ela, adicionando que, para o jornalismo de ambos, aquilo poderia significar "a nossa guerra". Irritado, o homem que estava entre seus principais incentivadores na cobertura da luta dos republicanos contra os fascistas na Espanha, ironicamente rebate: "De quantas guerra você precisa?" Ela tenta contraargumentar - "Não pense nisto como uma guerra. Pense nisto como uma lua de mel paga" -, mas esbarra na negativa do já seu então marido - de papel passado e tudo -, o que pode transparecer um misto de ciúme, de inveja do sucesso jornalístico dela ou de resquícios de uma postura com tons patriarcais. Ou seja, em pauta questões de gênero: amor, casamento e poder. Mais adiante, ela lamenta para ela: "Não há lar para a minha esposa. Ela é casada com a guerra". No presente da narração, a longa entrevista para a tv com que esse filme se inicia, Gellhorn confessa à câmera - ou seja a nós, espectadores: "Éramos bons na guerra e, quando não havia guerras, criávamos uma dentro de casa. A batalha a qual não sobreviveríamos era a vida doméstica".

\section{Considerações finais}

Ao escolhermos o cinema, mais propriamente dois filmes de ficção, para buscarmos discutir algumas questões em torno do trinômio "História, cinema e gênero", levamos em consideração o potencial desse meio de comunicação em produzir uma densa representação social, seguindo o pensamento de Jacques Aumont (1995, p.98), que chega a detalhar esse potencial na própria dramaturgia de caracterização dos protagonistas ao afirmar que as tipologias de personagens frequentemente são representativas ao mesmo de um período da história do cinema bem como de um "período da sociedade". Essa característica proporcionaria, segundo ele, as possibilidades de abordagens de cunho antropológico aos 
filmes de ficção. Ao mesmo tempo, ao tomarmos o cinema, mesmo que de ficção (estamos tratando de duas cinebiografias romanceadas), como evidência histórica, procedemos de acordo com o pensamento do historiador cultural Peter Burke (2004), que defende o poder do filme de proporcionar ao espectador a sensação de "testemunhar os eventos". Argumento a que se junta o do historiador cultural norte-americano Robert Rosenstone (2010, p.18): “Os filmes históricos, mesmo quando sabemos que são representações fantasiosas ou ideológicas, afetam a maneira como vemos o passado. Na maioria dos casos, esse efeito é sutil, mas ainda assim é um efeito".

Ao propormos aqui uma leitura de dois filmes norte-americanos de ficção, no subgênero biografia (biographical picture, abreviadamente biopic) ou docudrama numa edição sobre o tema "História, cinema e gênero", estamos atentos ao que se deve colocar cautelosamente antes das análises fílmicas propriamente ditas. Nesse sentido, é valiosa a contribuição de Rosenstone (2010) quando aponta alguns elementos fundamentais do que se entende comumente como a tradição hollywoodiana:

a) o filme insiste na história como o relato da vida de indivíduo, homens e mulheres que são conhecidos ou que são transformados em personagens importantes porque foram escolhidos pela câmera;

b) o filme nos oferece a história como um enredo de um passado unitário, fechado e acabado;

c) o filme personaliza, dramatiza e imprime emoção ao passado. Ele nos oferece a história como triunfo, angústia, felicidade, desespero, aventura, sofrimento e heroísmo; e

d) o longa-metragem comercial conta o passado como uma narrativa com começo, meio e fim. Uma narrativa que oferece ao espectador uma mensagem moral e (geralmente) uma sensação de exaltação.

A despeito das restrições colocadas acima por Rosenstone aos biopics ou aos docudramas, como os dois filmes a serem discutidos nesse ensaio, é estimulante notar-se como, tanto no Brasil como nos Estados Unidos e Europa, tantos historiadores de ofício têm dedicado parte significativa de sua produção científica à formação de grupos de pesquisa em torno das relações Cinema-História e, consequentemente, à elaboração de uma já volumosa e importante bibliografia a esse respeito. Por outro lado, historiadores que trabalham com imagens chamam a atenção para alguns dos efeitos colaterais da abordagem fílmica de reconstituições cinematográficas:

O poder do filme é que ele proporciona ao espectador uma sensação de testemunhar os eventos. Este também é o perigo do médium [...] porque esta sensação de testemunha é ilusória. $O$ diretor molda a experiência embora 
permanecendo invisível. E o diretor está preocupado não somente com o que aconteceu realmente, mas também em contar uma história que tenha forma artística e que possa mobilizar os sentidos de muitos espectadores. $O$ termo híbrido 'docudrama' é uma lembrança muito viva da tensão entre a ideia do drama e a ideia do documento, entre os anticlímaces e o caráter inacabado do passado e as necessidades do diretor como as do escritor, ou do pintor, de atender à forma (BURKE, 2004, p.200).

Enfim, como buscamos demonstrar, vários pontos em comum ligam as representações biográficas das repórteres norte-americanas Margareth Bourke-White e Martha Gellhorn. Além de terem enfrentado situações de risco por causa de suas ocupaçõestidas apenas como privilégio de uma certa masculinidade hegemônica -, preconceitos e desconfiança de colegas homens, todas as duas tiveram que lidar em suas vidas, em seus processos de afirmação pessoal e profissional, com um componente essencial das relações de gênero: o patriarcado. Conceito este que aponta para a domínio dos homens sobre as mulheres, incluindo a reprodução, a violência doméstica, a sexualidade, o trabalho, a cultura e o Estado, através de suas leis.

Margareth tivera que lutar na segunda metade dos anos 1920 nos Estados Unidos para poder entrar numa siderúrgica e lá fazer o que se chama no Brasil de "fotografia industrial". Depois, ela teria que brigar com dois maridos, o último deles um famoso romancista, para poder exercer a sua ocupação, viajando pelo mundo e correndo perigo, como se diz - ela cobriu, entre outros conflitos, a trajetória do exército de Patton na Segunda guerra mundial. Já Martha já era uma contista conhecida dos leitores de Colliers quando conheceu o monstro sagrado Ernest Hemingway. Enquanto concorriam com acesso a pautas de coberturas de conflitos pelo mundo, Martha tentava não se submeter ao código machista de "Papa", como ela depõe ao final de Hemingway \& Martha. Ao enumerar todas as guerras e conflitos que havia coberto em mais de 60 anos de carreira, ela é interrompida pelo entrevistador da tv. Este lhe diz que, para uma mulher ter feito tudo aquilo, era algo muito meritório especialmente por ter se exposto frequentemente ao perigo, associando, quem sabe, o seu perfil profissional à imagem alfa-macho que Hemingway havia sempre disseminado. Ao que ela responde, fechando os trabalhos: "Não sou complexada. Os homens é que o são. Eu não me vejo como uma nota de rodapé na vida de ninguém".

Acreditamos que os filmes elencados nesse ensaio, produzidos fora do auge do cinejornalismo ficcional de guerra (período da invasão norte-americana do Vietnã e nos 10 anos seguintes à derrota dos EUA no Sudeste Asiático e guerra na Bósnia), são uma boa 
amostra de uma reversão de uma sub-representação da mulher nessa modalidade, e uma reversão que aponta na direção de um sólido empoderamento feminino. Em todas as narrativas discutidas, as suas protagonistas enfrentam preconceito, ironia, discursos e práticas de masculinidade hegemônica, além de, todas elas casadas, se debaterem com tópicos relativos à cultura do patriarcalismo.

Se foram necessárias tantas décadas - entre Jejum de amor e Retratos de guerra para que uma repórter de texto ou de imagens pudesse voltar a ser a protagonista de um drama hollywoodiano, foram necessárias outras tantas até que uma revista da área de Ciências Sociais Aplicadas, como essa que você está lendo, pudesse pautar o tema "História, cinema e gênero", especialmente se essa chamada pudesse abrigar representações de mulheres como repórteres de guerra. Afinal, não entendiam muitos que guerra era coisa de homem? Entre esses muitos, havia aqueles que haviam recusado, por motivos de sexismo, o credenciamento das cinebiografadas Margareth e Martha para cobrirem as ações do Exército norte-americano na Segunda guerra mundial, entre outras. Por outro lado, na realidade imediata, durante um certo tempo, discussões sobre questões de gênero pareciam para muitos - aqueles com poder decisório - um tema secundário diante da "grande questão" das "grandes narrativas", como a luta de classes, por exemplo.

\section{REFERÊNCIAS BIBLIOGRÁFICAS}

AUMONT, Jacques. A estética do filme. Campinas, SP: Papirus, 1995.

BEAUVOIR, Simone. O segundo sexo 2. Rio de Janeiro: Nova Fronteira, 1980 [1949].

BURKE, P. História e teoria social, 2002. São Paulo: EDUNESP, 2002 [1992].

BURKE, Peter. Testemunha ocular: história e imagem. Bauru,SP: EDUSC, 2004.

GELLHORN, Martha. A face da guerra. Rio de Janeiro: Objetiva, 2009.

QUÉTEL, Claude. As mulheres na guerra, 1939-1945, vol.2. São Paulo: Larousse, 2009.

REAR window (Janela indiscreta). Alfred Hitchcock, 1956.

ROSENSTONE, Robert. A história nos filmes. Os filmes na história. São Paulo: Paz e Terra, 2010.

SENRA, Stella. O último jornalista: imagens de cinema. São Paulo: Estação Liberdade, 2ạ ed., 1997.

THE girl Friday (Jejum de amor). Howard Hawks, EUA, 1940. 
TRAQUINA, Nelson. Teorias do Jornalismo. Florianópolis: Insular, 2005.

WHELAN, Richard. "Introdução". In CAPA, Robert. Ligeiramente fora de foco. São Paulo: Cosac Naify, 2010. 